\author{
M.I. Tleubergenov ${ }^{1}$, D.T. Azhymbaev ${ }^{2}$ \\ ${ }^{1}$ Institute of Mathematics and Mathematical Modeling, Almaty, Kazakhstan; \\ ${ }^{2}$ K. Zhubanov Aktobe Regional State University, Kazakhstan \\ (E-mail: marat207@mail.ru)
}

\title{
Stochastical problem of Helmholtz for Birkhoff systems
}

\begin{abstract}
The Helmholtz problem is considered in a probabilistic formulation. By a given stochastic Langevin-Itô equation in an indirect representation, as the equation of the Hamiltonian structure and the equation of the Birkhoffian structure are constructed. The functional that takes a stationary value on solutions of a given stochastic Birkhoff equation, is defined by the method of moment functions. The obtained results are illustrated by two examples: 1) the plane motion of a symmetric satellite in a circular orbit under the action of gravity and aerodynamic forces, and 2) the fluctuation motion of a gyroscope in a gimbal caused by the stochastic fluctuating moment of forces along the suspension axis of the inner ring.
\end{abstract}

Keywords: stochastic Langevin-Itô equation, inverse problem, equation of the Hamiltonian (or Birkhoffian) structure.

\section{Introduction}

The theory of inverse problems of differential systems is sufficiently fully developed in [1-6, etc.] for deterministic systems, which are described by ordinary differential equations (ODE). Thus, the work of N.P. Erugin [1], in which a set of ODE is constructed according to a given integral curve, subsequently turned out to be fundamental in the formation and development of the theory of inverse problems of the dynamics of systems described by the ODE. In [2-6], the formulation, classification of inverse problems of differential systems and general methods for their solution in the class of ODE are presented. Also, in the ODE class, inverse problems of the automatic control systems' dynamics are considered [7-9]. It should be noted that one of the general methods for solving inverse problems of dynamics in the class of ODE is the quasi-inversion method proposed in $[4,5]$ and which makes it possible to obtain necessary and sufficient conditions for solvability.

A new stage in the research of inverse problems of differential systems is the increased interest in recent years in the study of the Helmholtz problem (see, for example, the monograph [10]). In the monograph of A.S. Galiullin [10], along with a review of works, the Hamilton systems' generalization in the sense of the reducibility of the non-conservative mechanical systems' motion equations to classical equations of dynamics is considered, and, in particular, the problem of the equations' Hamiltonization of program motion's systems is solved.

The classical Helmholtz problem [11] is the problem of construction the equivalent differential equations in the form of Lagrange on given second-order ordinary differential equations. Moreover, the equations for which such transition is possible are called Helmholtz systems. In the works of A. Mayer [12] and G.K. Suslov [13] independently it is shown that the classical Helmholtz conditions are not only necessary, but also sufficient conditions for the transition from Newtonian equations to Lagrangian ones.

The solving of the Helmholtz problem [11] in this or that class of differential equations allows us to extend to this class of equations well-developed mathematical methods of classical mechanics. It should be noted that the two-volume monograph by R. M. Santilli $[14,15]$, devoted to the problem of representation of ordinary differential equations of the second order in the form of Lagrange, Hamilton and Birkhoff, occupies a special place in the completeness of the material and the variety of Helmholtz problem's study aspects.

The development of methods for solving inverse problems in the class of partial differential equations is discussed in [16-18].

In [19-21], inverse problems of dynamics are considered in a probabilistic formulation under the additional assumption of the random perturbations' presence, and, in particular, the follow problems: 1) the basic inverse problem of dynamics, in which it is required to construct a set of second-order stochastic differential equations of Itô type having a given integral manifold, 2) the problem of reconstructing the equations of motion, in which 
it is required to construct a set of control parameters that enter into a given system of second-order stochastic differential equations of Itô type from a given integral manifold, and 3) the problem of closing the equations of motion, in which it is required to construct a set of closed stochastic second-order differential equations of Itô type with respect to a given system of equations and a given integral manifold, are solved by the quasi-inversion method.

In this paper, we consider the Helmholtz problem in the presence of random perturbations of white noise type for Hamilton systems and Birkhoff systems.

\section{Formulation of the problem and its solving}

It is required to construct an equivalent equation of the Hamiltonian (or Birkhoffian) structure by the equation given in the Langevin-Itô form

$$
\ddot{x}_{\nu}=F_{\nu}(x, \dot{x}, t)+\sigma_{\nu j}(x, \dot{x}, t) \dot{\xi}^{j} .
$$

Here $\xi^{j}=\xi_{0}^{j}+\int c^{j}(y) P^{0}(t, d y)$, where, following [22], $\xi_{0}^{j}$ is the Wiener process, $P^{0}$ is the Poisson process, $P^{0}(t, d y)$ is the number of process jumps $P^{0}$ in the interval $[0, t]$, falling on the set $d y$, where $y=\left(x^{T}, \dot{x}^{T}\right)^{T}$.

We say that a function $g(y, t)$ from the class $K, g \in K$, if $g$ is continuous on $t$ and is Lipschitz on $y$ in the whole space $R^{2 n}$ э $y$ and satisfies the linear growth condition with respect to $y$ : $\|g(y, t)\| \leq M(1+\|y\|)$ with some constant $M$.

Suppose that a given vector-valued function $F$ and a matrix $\sigma$ belong to the class $K$. And since the vectorvalued function $F$ and the $(n \times k)$ matrix $\sigma$ are assumed from the class $K$, this ensures [22] the existence and uniqueness up to the stochastic equivalence of the solution $\left(x^{T}(t), \dot{x}^{T}(t)\right)^{T}$ of equation $(1)$ with the initial condition $\left(x\left(t_{0}\right)^{T}, \dot{x}\left(t_{0}\right)^{T}\right)^{T}=\left(x_{0}^{T}, \dot{x}_{0}^{T}\right)^{T}$ being a strictly Markov process with probability 1.

This formulation of the problem in the absence of random perturbations $\left(\sigma_{\nu j} \equiv 0\right)$ was considered in the works of R.M. Santilli [14, 15], and in a probabilistic formulation the Helmholtz problem it was previously studied in [23-25], where equations of the Lagrangian structure are constructed from the given equation (1), and, further, from the stochastic Lagrange equation, a stochastic analogue of the Hamilton variational principle is determined.

To solve the problem, we will introduce previously a new variable and we will rewrite the given equation (1) in a form

$$
\left\{\begin{array}{l}
\dot{x}_{k}=y_{k} \\
\dot{y}_{k}=F_{k}(x, y, t)+\sigma_{k j}(x, y, t) \dot{\xi}^{j}
\end{array}\right.
$$

And then, with the help of replacements

$$
\begin{gathered}
a_{k}=\left\{\begin{array}{l}
x_{k} \\
y_{k}
\end{array} ; \quad \eta_{j}=\left\{\begin{array}{l}
0, j=1,2, \ldots, n ; \\
\xi^{j-n}, \quad j=n+1, n+2, \ldots, n+m ;
\end{array}\right.\right. \\
G_{k}=\left\{\begin{array}{l}
x_{k} \\
F_{k}
\end{array} ; \quad \Lambda=\left(\Lambda_{k j}\right)=\left(\begin{array}{ll}
0_{n \times n} & 0_{n \times m} \\
0_{n \times n} & \sigma_{n \times m}
\end{array}\right) ; \quad \sigma=\left(\sigma_{\mu j}\right),\right.
\end{gathered}
$$

we rewrite the equation (2) in a form

$$
\dot{a}_{k}=G_{k}(a, t)+\Lambda_{k j}(a, t) \dot{\eta}_{j} .
$$

Further, we rewrite the stochastic equation of the Hamiltonian structure

$$
\left\{\begin{array}{l}
\dot{q}_{k}=\frac{\partial H}{\partial p_{k}} \\
\dot{p}_{k}=-\frac{\partial H}{\partial q_{k}}+\sigma_{k j}^{\prime}(q, p, t) \dot{\xi}^{j}, \quad(k=\overline{1, n}) .
\end{array}\right.
$$

in the form

where the following notations are

$$
\dot{z}_{\mu}-\alpha_{\mu \nu} \frac{\partial H}{\partial z_{\nu}}=\theta_{\mu \nu} \dot{\eta}_{\nu}
$$




$$
\begin{gathered}
z_{k}= \begin{cases}q_{k}, & k=1,2, \ldots, n, \\
p_{k-n}, & k=n+1, n+2, \ldots, 2 n,\end{cases} \\
\alpha=\left(\alpha_{\mu \nu}\right)=\left(\begin{array}{cc}
0_{n \times n} & I_{n \times n} \\
-I_{n \times n} & 0_{n \times n}
\end{array}\right), \quad \Theta=\left(\theta_{\mu \nu}\right)=\left(\begin{array}{cc}
0_{n \times n} & 0_{n \times m} \\
0_{n \times n} & \sigma_{n \times m}^{\prime}
\end{array}\right) ; \\
\left(\begin{array}{c}
\frac{\partial H}{\partial q_{k}} \\
-\frac{\partial H}{\partial p_{k}}
\end{array}\right)=\left(\alpha_{\mu \nu} \frac{\partial H}{\partial z_{\nu}}\right) .
\end{gathered}
$$

Or, if we introduce a matrix $\left(\omega_{\mu \nu}\right)$ which is the inverse to a matrix $\left(\alpha_{\mu \nu}\right)$

$$
\left(\omega_{\mu \nu}\right)=\left(\alpha_{\mu \nu}\right)^{-1}=\left(\begin{array}{cc}
0_{n \times n} & -I_{n \times n} \\
I_{n \times n} & 0_{n \times n}
\end{array}\right)
$$

and $2 n$-dimensional vector

$$
a_{\mu} \equiv \omega_{\mu \nu} z_{\nu}=\left(\begin{array}{cc}
-p_{\mu}, & \mu=1,2, \ldots, n \\
q_{\mu-n}, & \mu=n+1, n+2, \ldots, 2 n
\end{array}\right),
$$

then the equation (5) will be transformed to the equivalent equation

$$
\omega_{\mu \nu} \dot{a}_{\nu}-\frac{\partial H}{\partial a_{\nu}}=\omega_{\mu k} \theta_{k \nu} \dot{\eta}_{\nu}
$$

Construction of the Hamiltonian in the indirect representation. We consider the problem of the indirect representation of equation (3) in the form of an equation of the Hamiltonian structure (6), that is, with the aid of a certain matrix $\Gamma=\left(\gamma_{\nu}^{k}\right)$, we consider the relation

$$
\gamma_{\nu}^{k}\left(\dot{a}_{k}-G_{k}-\Lambda_{k j} \dot{\eta}_{j}\right) \equiv \omega_{\nu \mu} \dot{a}_{\mu}-\frac{\partial H}{\partial a_{\nu}}-\omega_{\nu k} \theta^{k j} \dot{\eta}_{j}
$$

or

$$
\left.C_{\nu k} \dot{a}_{k}-D_{\nu}(a, t)-\gamma_{\nu}^{k} \Lambda_{k j} \dot{\eta}_{j}\right) \equiv \omega_{\nu \mu} \dot{a}_{\mu}-\frac{\partial H}{\partial a_{\nu}}-\omega_{\nu k} \theta^{k j} \dot{\eta}_{j},
$$

where $C_{\nu k}=\gamma_{\nu}^{k} ; \quad D_{\nu}(a, t)=\gamma_{\nu}^{k} G_{k}$.

To satisfy the identity ( 7$)$, it is required the fulfillment of conditions

$$
\begin{gathered}
C_{\nu k}=\omega_{\nu k}, D_{\nu}(a, t)=-\frac{\partial H}{\partial a^{\nu}}, \\
\gamma_{\nu}^{k} \Lambda_{k j}=\omega_{\nu k} \theta^{k j},(\nu, k=\overline{1,2 n}, j=\overline{1, n+m}) ; \\
\gamma_{\nu}^{k}=\omega_{\nu k} .
\end{gathered}
$$

From (9) and (10), it follows that the equality

$$
\sigma_{k j}=\sigma_{k j}^{\prime}, \quad(k=\overline{1, n}, j=\overline{1, m})
$$

takes place.

Hence, we have

Theorem 1. The indirect representation of the stochastic equation (3) in the form of the stochastic Hamilton equation (6) is possible if and only if conditions (8), (10), (11) are satisfied.

Remark. To construct the Hamilton function, which determines the form of equation (6), it is necessary to check the Helmholtz conditions for the given equation, which, following R.M. Santilli [14], represent the next relations:

$$
\begin{gathered}
C_{\mu \nu}+C_{\nu \mu}=0 ; \\
\frac{\partial C_{\mu \nu}}{\partial a_{\tau}}+\frac{\partial C_{\nu \tau}}{\partial a_{\mu}}+\frac{\partial C_{\tau \mu}}{\partial a_{\nu}}=0 ; \\
\frac{\partial C_{\mu \nu}}{\partial t}=\frac{\partial D_{\mu}}{\partial a_{\nu}}-\frac{\partial D_{\nu}}{\partial a_{\mu}} .
\end{gathered}
$$


Construction of the Birkhoffian in an indirect representation. We consider the stochastic Helmholtz problem in the following formulation: it is required to construct a stochastic equation of the Birkhoffian structure of the form

$$
\left[\frac{\partial R_{\nu}(a, t)}{\partial a_{\mu}}-\frac{\partial R_{\mu}(a, t)}{\partial a_{\nu}}\right] \dot{a}_{\nu}-\left[\frac{\partial B(a, t)}{\partial a_{\mu}}+\frac{\partial R_{\mu}(a, t)}{\partial t}\right]=T_{\mu j} \dot{\eta}_{j}
$$

by the given equation

$$
C_{\mu \nu} \dot{a}_{\nu}-D_{\nu}(a, t)=\Lambda_{\mu j} \dot{\eta}_{j}, \quad(\mu, \nu=\overline{1,2 n})
$$

where $B=B(a, t)$ is called the Birkhoff function, and $W=\left(W_{\mu \nu}\right)$ is the Birkhoff tensor [15] with components $W_{\mu \nu}=\frac{\partial R_{\nu}(a, t)}{\partial a_{\mu}}-\frac{\partial R_{\mu}(a, t)}{\partial a_{\nu}}$.

The Birkhoff system (15) is a direct generalization of Hamilton systems (6). Indeed, when $a_{\nu}=q_{\nu}(\nu=\overline{1, n})$, $a_{\nu}=p_{\nu-n}(\nu=\overline{n+1,2 n}) ; R_{\nu}=p_{\nu}(\nu=\overline{1, n}), R_{\nu}=0(\nu=\overline{n+1,2 n}) ; B(a, t)=H(q, p, t)$ equation (15) takes the form of the canonical equations (6).

To solve this problem, we consider the relation

$$
C_{\mu \nu} \dot{a}_{\nu}-D_{\nu}(a, t)-\Lambda_{\mu j} \dot{\eta}_{j} \equiv\left(\frac{\partial R_{\nu}(a, t)}{\partial a_{\mu}}-\frac{\partial R_{\mu}(a, t)}{\partial a_{\nu}}\right) \dot{a}_{\nu}-\left(\frac{\partial B(a, t)}{\partial a_{\mu}}+\frac{\partial R_{\mu}(a, t)}{\partial t}\right)-T_{\mu j} \dot{\eta}_{j},
$$

which is fulfilled identically under the following conditions:

$$
\begin{gathered}
C_{\mu \nu}(a, t)=\frac{\partial R_{\nu}(a, t)}{\partial a_{\mu}}-\frac{\partial R_{\mu}(a, t)}{\partial a_{\nu}} ; \\
D_{\nu}(a, t)=\frac{\partial B(a, t)}{\partial a_{\mu}}+\frac{\partial R_{\mu}(a, t)}{\partial t} ; \\
\Lambda_{\mu j}=T_{\mu j} .
\end{gathered}
$$

Consequently, we have

Theorem 2. The direct representation of the stochastic equation (16) in the form of the stochastic Birkhoff equation (15) is possible if and only if conditions (17)-(19) are satisfied.

Indirect representation of the stochastic Hamilton equation in the form of a stochastic Birkhoff equation. We consider the problem of indirect construction of the Birkhoff equation (15) from a given Hamiltonian equation (6) in the presence of random perturbations.

In other words, we will define $R_{\nu}$ and $B$ on given functions $H$ and $h_{\mu}^{\alpha}$ so that the relation

$$
h_{\mu}^{\alpha}\left[\omega_{\alpha \beta} \dot{a}_{\beta}-\frac{\partial H}{\partial a_{\alpha}}-T^{\alpha j} \dot{\eta}_{j}\right]=\left(\frac{\partial R_{\nu}(a, t)}{\partial a_{\mu}}-\frac{\partial R_{\mu}(a, t)}{\partial a_{\nu}}\right) \dot{a}_{\nu}-\left(\frac{\partial B(a, t)}{\partial a_{\mu}}+\frac{\partial R_{\mu}(a, t)}{\partial t}\right)-T_{\mu j}^{\prime} \dot{\eta}_{j}
$$

be satisfied. The relation (20) turns into an identity when the relations

$$
\begin{gathered}
h_{\mu}^{\alpha} \omega_{\alpha \nu}=\frac{\partial R_{\nu}(a, t)}{\partial a_{\mu}}-\frac{\partial R_{\mu}(a, t)}{\partial a_{\nu}} ; \\
h_{\mu}^{\alpha} \frac{\partial H}{\partial a_{\alpha}}=\frac{\partial B(a, t)}{\partial a_{\mu}}+\frac{\partial R_{\mu}(a, t)}{\partial t} ; \\
h_{\mu}^{\alpha} T^{\alpha j}=T_{\mu j}^{\prime} .
\end{gathered}
$$

are performed.

Consequently, we have

Theorem 3. The indirect representation of the stochastic Hamilton equation (6) in the form of a stochastic Birkhoff equation (15)is possible if and only if there exist $4 n^{2}$ functions $h_{\mu}^{\alpha}$ such that conditions (21)-(23) are satisfied for given functions $H, R_{\mu}, B, T, T^{\prime}$.

Birkhoffian action in the stochastic Helmholtz problem. The Helmholtz problem in the class of LangevinIto stochastic differential equations is divided into two interrelated problems. At the first stage, a stochastic analog of the Lagrange, Hamilton or Birkhoff equations is constructed from the given equation. And further, 
in the second stage, the required functional (Hamiltonian or Birkhoffian action) must be constructed from the constructed $L, H$ or $B$ with $R$.

In this section, one of the options for constructing a stochastic analog of the Birkhoff action is considered.

Let us consider the stochastic equation of the Lagrangian structure

$$
\frac{d}{d t}\left(\frac{\partial L}{\partial \dot{q}_{\nu}}\right)-\frac{\partial L}{\partial q_{\nu}}=\sigma_{\nu j}(q, \dot{q}, t) \dot{\xi}^{j}, \quad(\nu=\overline{1, n}),
$$

which is assumed, following the works [23-25], constructed in direct or indirect representation by the given equation (1).

Then the averaged Lagrangian $M L$ will satisfy [23] the following equation

$$
\frac{d}{d t}\left(\frac{\partial M L}{\partial \dot{q}_{\nu}}\right)-\frac{\partial M L}{\partial q_{\nu}}=0 .
$$

From the function $M L$ by the Legendre transform, we define the averaged Hamiltonian $\tilde{H}=p_{i} q_{i}-M L$, which generates the following canonical equation

$$
\left\{\begin{array}{l}
\frac{d q_{i}}{d t}=\frac{\partial \tilde{H}}{\partial p_{i}} \\
\frac{d p_{i}}{d t}=-\frac{\partial \tilde{H}}{\partial q_{i}}, \quad(i=\overline{1, n}),
\end{array}\right.
$$

or in variables $a=\left(a_{1}, a_{2}, \ldots, a_{2 n}\right)$ the following canonical equation of the type of equation (6)

$$
\omega_{\mu \nu} \dot{a}_{\nu}-\frac{\partial \tilde{H}}{\partial a_{\nu}}=0
$$

Further, on the basis of Theorem 3 by the equation $\left(24^{\prime}\right)$, we construct a set $(\tilde{R}, \tilde{B})$ generating the Birkhoff equation $(25)$

$$
\left[\frac{\partial \tilde{R}_{\nu}(a, t)}{\partial a_{\mu}}-\frac{\partial \tilde{R}_{\mu}(a, t)}{\partial a_{\nu}}\right] a_{\nu}-\left[\frac{\partial \tilde{B}(a, t)}{\partial a_{\mu}}+\frac{\partial \tilde{R}_{\mu}(a, t)}{\partial t}\right]=0,
$$

which is equivalent to the indirect Hamilton equation (26)

$$
h_{\mu}^{\alpha}\left(\omega_{\alpha \beta} \dot{a}_{\beta}-\frac{\partial \tilde{H}}{\partial a_{\alpha}}\right)=0
$$

under the conditions (27), (28)

$$
\begin{aligned}
h_{\mu}^{\alpha} \omega_{\alpha \nu} & =\frac{\partial \tilde{R}_{\nu}(a, t)}{\partial a_{\mu}}-\frac{\partial \tilde{R}_{\mu}(a, t)}{\partial a_{\nu}} ; \\
h_{\mu}^{\alpha} \frac{\partial \tilde{H}}{\partial a_{\alpha}} & =\frac{\partial \tilde{B}(a, t)}{\partial a_{\mu}}+\frac{\partial \tilde{R}_{\mu}(a, t)}{\partial t} .
\end{aligned}
$$

Then the functional taking the stationary value on the solutions of equation (1) is constructed in the form of an average Birkhoffian action in the form

$$
\tilde{S}=\int_{t_{1}}^{t_{2}}\left[\tilde{R}_{\nu}(a, t) \dot{a}_{\nu}-\tilde{B}(a, t)\right] d t .
$$

Examples. We will consider the problem of constructing the Hamiltonian and Birkhoff functions for specific stochastic equations using the statements proved above.

Example 1. Let us consider the plane motion of a symmetric satellite along a circular orbit under the assumption of a pitch change under the influence of gravitational forces and aerodynamic forces [26, 27]

$$
\ddot{\theta}=f(\theta, \dot{\theta})+\sigma(\theta, \dot{\theta}) \dot{\xi},
$$


where $\theta$ is the pitch angle and the functions $f$ and $\sigma$ have the form

$$
f=M l \sin 2 \theta-M[g(\theta)+\eta \dot{\theta}], \quad \sigma=M \delta[g(\theta)+\eta \dot{\theta}] .
$$

In work [23], the problem of indirect construction of the Lagrangian on the given equation (29) was considered

$$
h[\ddot{\theta}-f(\theta, \dot{\theta})-\sigma(\theta, \dot{\theta}) \dot{\xi}]=0
$$

at $h=e^{-Q \eta t}$. The required Lagrangian for $\left(29^{\prime}\right)$ was constructed in the form

$$
L=e^{-Q \eta t}\left[\frac{1}{2} \dot{\theta}^{2}-Q\left(\frac{1}{2} l \cos 2 \theta+G\right)\right], \quad \text { where } \quad G=\int g(\theta) d \theta,
$$

which provides a representation $\left(29^{\prime}\right)$ in the form of an equation of the Lagrangian structure

$$
\frac{d}{d t} \frac{\partial L}{\partial \dot{\theta}}-\frac{\partial L}{\partial \theta}=e^{-Q \eta t} \sigma(\theta, \dot{\theta}) \dot{\xi}
$$

We will consider the problem of indirect construction of the Hamiltonian according to given equation (29). Namely, using the Lagrange function (30) and the Legendre transformation, we will define the Hamilton function in the form

$$
H=\chi \dot{\theta}-\left.L(\theta, \dot{\theta}, t)\right|_{\dot{\theta}=\dot{\theta}(\theta, \chi, t)} .
$$

And since $\chi=\frac{\partial L}{\partial \dot{\theta}}$, then $\chi=e^{-Q \eta t} \dot{\theta}$, and, consequently, $\dot{\theta}=e^{Q \eta t} \chi$. Then the canonical equation corresponding to equation (31) will take the form

$$
\left\{\begin{array}{l}
\dot{\theta}=\frac{\partial H}{\partial \chi} \\
\dot{\chi}=-\frac{\partial H}{\partial \theta}+\tilde{\sigma}(\theta, \chi, t) \dot{\xi},
\end{array}\right.
$$

where $\tilde{\sigma}=\left.\sigma^{\prime}(\theta, \dot{\theta}, t)\right|_{\dot{\theta}=\dot{\theta}(\theta, \chi, t)}$, and the Hamilton function is defined in the form

$$
H=\frac{1}{2} e^{Q \eta t} \chi^{2}-e^{-Q \eta t} \beta(\theta) .
$$

To solve the problem of the indirect representation of the Birkhoffian for a given equation (29), we will use Theorem 3. By the equation (32) constructed above and the Hamilton function (33) from relation (20) with $\left(h_{\mu \nu}\right)=\left(\begin{array}{ll}h & 0 \\ 0 & h\end{array}\right)$, functions $R_{\mu}(\mu=1,2)$ and $B$ are defined in the follow form $R_{\mu}=\{\chi,(1+h) \theta\}$, $B=\frac{1}{2} h e^{Q \eta t} \chi^{2}-h e^{-Q \eta t} \beta(\theta)$, where $h$ is an arbitrary constant.

Example 2. Let us consider a second-order nonlinear differential equation describing the motion of the inner ring of a gyroscope in a gimbal [28]

$$
\ddot{\beta}+2 \nu \dot{\beta}+f(\beta)=\dot{\xi},
$$

where $\beta$ is the angle of rotation of the inner ring. Here there is the coefficient at white noise $\sigma=1$.

In [23], the problem of indirect construction of the Lagrangian on the given equation (34)

$$
h[\ddot{\beta}+2 \nu \dot{\beta}+f(\beta)]=\dot{\xi}
$$

was considered at $h=e^{2 \nu t}$. And the required Lagrangian for $\left(34^{\prime}\right)$ was constructed in the form

$$
L=e^{2 \nu t}\left[\frac{1}{2} \dot{\beta}^{2}-\gamma(\beta)\right], \quad \text { where } \frac{d}{d t} \gamma(\beta)=f(\beta),
$$

providing the representation $\left(34^{\prime}\right)$ in the form of an equation of Lagrangian structure

$$
\frac{d}{d t}\left(\frac{\partial L}{\partial \dot{\beta}}\right)-\frac{\partial L}{\partial \beta}=e^{2 \nu t} \dot{\xi}
$$


Similarly to Example 1, we consider the problem of the indirect representation of the Hamiltonian and the Birkhoffian. We will define the Hamilton function by the Legendre transformation of the Lagrange function

$$
H=\chi \dot{\beta}-\left.L(\beta, \dot{\beta}, t)\right|_{\dot{\beta}=\dot{\beta}(\beta, \chi, t)}=\frac{1}{2} e^{-2 \nu t} \chi^{2}+e^{2 \nu t} \gamma(\beta),
$$

which generates the stochastic Hamilton equation of the form

$$
\left\{\begin{array}{l}
\dot{\theta}=\frac{\partial H}{\partial \chi} \\
\dot{\chi}=-\frac{\partial H}{\partial \theta}+e^{2 \nu t} \dot{\xi}
\end{array}\right.
$$

that is equivalent to the Lagrange equation (35). Further, according to the equation (36) and the relation (20) with $\left(h_{\mu \nu}\right)=\left(\begin{array}{cc}\alpha & 0 \\ 0 & \alpha\end{array}\right)$, functions $R_{\mu}(\mu=1,2)$ and $B$ are defined in the follow form

$$
R_{\mu}=\{\chi,(1+\alpha) \beta\}, \quad B=\frac{1}{2} \alpha e^{-2 \nu t} \chi^{2}+\alpha e^{2 \nu t} \gamma(\beta),
$$

where $\alpha$ is an arbitrary constant.

In particular, the unknown functions take the form $R_{\mu}=\{\chi, 2 \beta\}, B \equiv H$ at $\alpha=1$.

This research was supported by the Committee of Science of the Ministry of Education and Science of the Republic of Kazakhstan (Grant No. AP05131369).

\section{References}

1 Еругин Н.П. Построение всего множества систем дифференциальных уравнений, имеющих заданную интегральную кривую / Н.П. Еругин // Прикладная математика и механика. - 1952. - Т. 10, № 6. - C. 659-670.

2 Галиуллин А.С. Методы решения обратных задач динамики / А.С. Галиуллин. - М.: Наука, 1986. $-224 \mathrm{c}$.

3 Галиуллин А.С. Построение поля сил по заданному семейству траекторий / А.С. Галиуллин // Дифференциальные уравнения. - 1981. - Т. 17, № 8. - С. 1487-1489.

4 Мухаметзянов И.А. Уравнения программных движений / И.А. Мухаметзянов, Р.Г. Мухарлямов. М.: Изд-во Ун-та дружбы народов им. П. Лумумбы, 1986. - 88 с.

5 Мухарлямов Р.Г. О построении систем дифференциальных уравнений движения механических систем / Р.Г. Мухарлямов // Дифференциальные уравнения. - 2003. - Т. 39, № 3. - С. 343-353.

6 Мухарлямов Р.Г. Моделирование процессов управления, устойчивость и стабилизация систем с программными связями / Р.Г. Мухарлямов // Известия РАН. Теория и системы управления. - 2015. № 1. - C. $15-28$.

7 Zhumatov S.S. Stability of a program manifold of control systems with locally quadratic relations / S.S. Zhumatov // Ukrainian Mathematical Journal. - 2009. - Vol. 61, No. 3. - P. 500-509.

8 Zhumatov S.S. Exponential stability of a program manifold of the indirect control systems / S.S. Zhumatov // Ukrainian Mathematical Journal. - 2010. - Vol. 62, No. 6. - P. 907-915.

9 Zhumatov S.S. Asymptotic stability of implicit differential systems in the vicinity of program manifold / S.S. Zhumatov // Ukrainian Mathematical Journal. - 2014. - Vol. 66, No. 4. - P. 625-632.

10 Галиуллин А.С. Системы Гельмгольца / А.С. Галиуллин. - М.: Наука, 1995. - 86 с.

11 Гельмгольц Г. О физическом значении принципа наименьшего действия / Г. Гельмгольц // Вариационные принципы механики. - М.: Наука, 1959. - С. 430-459.

12 Mayer A. Die existenzbeingungen eines kinetischen potentiales / A. Mayer // Ber. Verhand. Kgl. Sachs. Ges. Wiss. - Leipzig, 1896. - Vol. 48. - P. 519-529.

13 Суслов Г.К. О кинетическом потенциале Гельмгольца / Г.К. Суслов // Математический сборник. 1896. - Т. 19, № 1. - C. 197-210. 
14 Santilli R.M. Foundations of Theoretical Mechanics. 1. The Inverse Problem in Newtonian Mechanics / R.M. Santilli. - New York: Springer-Verlag, 1978. - 266 p.

15 Santilli R.M. Foundation of Theoretical Mechanics. 2. Birkhoffian Generalization of Hamiltonian Mechanics / R.M. Santilli. - New York: Springer-Verlag, 1983. - 370 p.

16 Budochkina S.A. An operator equation with the second time derivative and Hamilton-admissible equations / S.A. Budochkina, V.M. Savchin // Doklady Mathematics. - 2016. - Vol. 94, No. 2. - P. 487-489.

17 Savchin V.M. Nonclassical Hamilton's actions and the numerical performance of variational mathodssfor some dissipative problems. Springer, Cham / V.M. Savchin, S.A. Budochkina // Communications in Computer and Information Science. - 2016. - Vol. 678. - P. 624-634.

18 Savchin V.M. Invariance of functionals and related Euler-Lagrange equations / V.M. Savchin, S.A. Budochkina // Russian Mathematics. - 2017. - Vol. 61, No. 2. - P.49-54.

19 Тлеубергенов М.И. Об обратной задаче динамики при наличии случайных возмущений / М.И. Тлеубергенов // Известия МН-АН РК. Сер. физ.-мат. - Алматы, 1998. - № 3. - С. 55-61.

20 Tleubergenov M.I. An inverse problem for stochastic differential systems / M.I. Tleubergenov // Differential Equations. - 2001. - Vol. 37. - No. 5. - P. 711-753.

21 Тлеубергенов М.И. Об обратной стохастической задаче замыкания / М.И. Тлеубергенов // Доклады МН-АН РК. - Алматы, 1999. - № 1. - С. 53-60.

22 Пугачев В.С. Стохастические дифференциальные системы. Анализ и фильтрация / В.С. Пугачев, И.Н. Синицын. - М., 1990. - 632 с.

23 Тлеубергенов М.И. К обратной задаче ньютоновой механики в вероятностной постановке / М.И. Тлеубергенов // Деп. в ВИНИТИ от 14.02.92. - № 499. - Вып. 92. - 54 с.

24 Тлеубергенов М.И. Метод дополнительных переменных в стохастической задаче Гельмгольца / М.И. Тлеубергенов // Известия МН-АН РК. Сер. физ.-мат. - Алматы, 1996. - № 1. - С. $49-54$.

25 Тлеубергенов М.И. К вопросу разрешимости стохастической задачи Гельмгольца / М.И. Тлеубергенов // Известия МН-АН РК. Сер. физ.-мат. - Алматы, 1996. - № 3. - С. 53-63.

26 Сагиров П. Стохастические методы в динамике спутников / П. Сагиров // Механика. Периодический сборник переводов иностранных статей. - 1974. - № 5(147). - С. 28-47.

27 Сагиров П. Стохастические методы в динамике спутников / П. Сагиров // Механика. Периодический сборник переводов иностранных статей. - 1974. - № 6(148). - С. 3-38.

28 Синицын И.Н. О флуктуациях гироскопа в кардановом подвесе / И.Н. Синицын // Известия АН СССР. Механика твердого тела. - 1976. - № 3. - С. 23-31.

М.Ы. Тілеубергенов, Д.Т. Әжімбаев

\title{
Биркгоф жүйелер үшін стохастикалық Гельмгольц есебі
}

\begin{abstract}
Ықтималдық қойылымда Гельмгольц есебі қарастырылды. Тура емес көрсетілуде берілген ЛанжевенИто стохастикалық теңдеуі бойынша Гамильтон және Биркгоф құрылымды теңдеулер тұрғызылды. Моменттік функциялар әдісі арқылы берілген стохастикалық Биркгоф теңдеуінің шешімдерінде стационарлық мән қабылдайтын функционал анықталды. Алынған нәтижелер екі мысалда суреттеледі: 1) тартылыс күші мен аэродинамикалық күш әсерімен айналмалы орбитада симметриялық спутниктің жазық қозғалысы және 2) ішкі сақинаның ілу осі бойынша күштердің стохастикалық флуктуалатын сәтінен туындаған кардан аспадағы гироскоптың флуктуациялық қозғалысы.
\end{abstract}

Kiлm сөздер: стохастикалық Ланжевен-Итоның теңдеуі, кері есебі, Гамильтон (немесе Биркгоф) құрылымды теңдеуі. 


\title{
Стохастическая задача Гельмгольца для систем Биркгофа
}

\begin{abstract}
Рассмотрена задача Гельмгольца в вероятностной постановке. По заданному стохастическому уравнению Ланжевена-Ито в непрямом представлении строится как уравнение гамильтоновой структуры, так и уравнение биркгофиановой структуры. Методом моментных функций определяется функционал, принимающий стационарное значение на решениях заданного стохастического уравнения Биркгофа. Полученные результаты иллюстрируются на двух примерах: 1) плоское движение симметричного спутника по круговой орбите под действием сил тяготения и аэродинамических сил и 2) флуктуационное движение гироскопа в кардановом подвесе, вызванное стохастическим флуктуирующим моментом сил по оси подвеса внутреннего кольца.
\end{abstract}

Ключевые слова: стохастическое уравнение Ланжевена-Ито, обратная задача, уравнение Гамильтоновой (или Биркгофиановой) структуры.

\section{References}

1 Erugin, N.P. (1952). Postroenie vseho mnozhestva sistem differentsialnykh uravnenii imeiushchikh zadannuiu krivuiu [Construction of the entire set of systems of differential equations having a given integral curve]. Prikladnaia matematika $i$ mekhanika - Applied Mathematics and Mechanics, Vol. 10, 659-670 [in Russian].

2 Galiullin, A.S. (1986). Metody resheniia obratnykh zadach dinamiki [Methods for solving inverse problems of dynamics]. Moscow: Nauka [in Russian].

3 Galiullin, A.S. (1981). Postroenie polia sil po zadannomu semeistvu traektorii [Construction of the force field from a given family of trajectories]. Differentsialnye uravneniia - Differential equations, Vol. 17, 1487-1489 [in Russian].

4 Mukhametzyanov, I.A., \& Mukharlyamov, R.G. (1986). Uravneniia prohrammnykh dvizhenii [Equations of program motions.] Moscow: Izdatelstvo Universiteta druzhby narodov imeni P. Lumumby [in Russian].

5 Mukharlyamov, R.G. (2003). O postroenii sistem differentsialnykh uravnenii dvizheniia mekhanicheskikh sistem [On the construction of differential equations' systems of mechanical systems' motion]. Differentsialnye uravneniia - Differential equations, Vol. 39, 343-353 [in Russian].

6 Mukharlyamov, R.G. (2015). Modelirovanie protsessov upravleniia, ustoichivost i stabilizatsiia sistem s prohrammnymi sviaziami [Modeling of control processes, stability and stabilization of systems with program relations]. Izvestiia RAN. Teoriia i sistemy upravleniia - News of the Russian Academy of Sciences. Theory and control systems, No. 1, 15-28 [in Russian].

7 Zhumatov, S.S. (2009). Stability of a program manifold of control systems with locally quadratic relations Ukrainian Mathematical Journal, Vol. 61, 500-509.

8 Zhumatov, S.S. (2010). Exponential stability of a program manifold of the indirect control systems. Ukrainian Mathematical Journal, Vol. 62, 907-915.

9 Zhumatov, S.S. (2014). Asymptotic stability of implicit differential systems in the vicinity of program manifold. Ukrainian Mathematical Journal, Vol. 66, 625-632.

10 Galiullin, A.S. (1995). Sistemy Helmgoltsa [Helmholtz systems]. Moscow: Nauka [in Russian].

11 Helmholtz, G. (1959). O fizicheskom znachenii printsipa naimensheho deistviia [On the physical significance of the principle of least action]. Variatsionnye printsipy mekhaniki - Variational principles of mechanics. Moscow: Nauka, 430-459 [in Russian].

12 Mayer, A. (1896). Die existenzbeingungen eines kinetischen potentiales. Ber. Verhand. Kgl. Sachs. Ges. Wiss. Leipzig, 519-529.

13 Suslov, G.K. (1896). O kineticheskom potentsiale Helmholtsa [On the Helmholtz kinetic potential]. Matematicheskii sbornik - Mathematical collection, Vol. 19, 197-210 [in Russian].

14 Santilli, R.M. (1978). Foundations of Theoretical Mechanics. 1. The Inverse Problem in Newtonian Mechanics. New York: Springer-Verlag. 
15 Santilli, R.M. (1983). Foundation of Theoretical Mechanics. 2. Birkhoffian Generalization of Hamiltonian Mechanics. New York: Springer-Verlag.

16 Budochkina, S.A., \& Savchin, V.M. (2016). An operator equation with the second time derivative and Hamilton-admissible equations. Doklady Mathematics, Vol. 94, 487-489.

17 Savchin, V.M., \& Budochkina, S.A. (2016). Nonclassical Hamilton's actions and the numerical performance of variational mathodssfor some dissipative problems. Springer, Cham. Communications in Computer and Information Science, Vol. 678, 624-634.

18 Savchin, V.M., \& Budochkina, S.A. (2017). Invariance of functionals and related Euler-Lagrange equations. Russian Mathematics, Vol. 61, 49-54.

19 Tleubergenov, M.I. (1998). Ob obratnoi zadache dinamiki pri nalichii sluchainykh vozmushchenii [On the inverse problem of dynamics in the presence of random perturbations]. Izvestiia Ministerstva naukiAkademii nauk Respubliki Kazakhstan. Seriia fiziko-matematicheskaia-News of the Ministry of ScienceAcademy of Sciences of the Republic of Kazakhstan. Series of physics and mathematics, 3, 55-61 [in Russian].

20 Tleubergenov, M.I. (2001). An inverse problem for stochastic differential systems. Differential Equations, Vol. 37, 711-753.

21 Tleubergenov, M.I. (1999). Ob obratnoi stokhasticheskoi zadache zamykaniia [On the inverse stochastic closure problem]. Doklady Ministerstva nauki Akademii nauk Respubliki Kazakhstan - Reports of the Ministry of Science Academy of Sciences of the Republic of Kazakhstan, 1, 53-60 [in Russian].

22 Pugachev, V.S., \& Sinitsyn, I.N. (1990). Stokhasticheskie differentsialnye sistemy. Analis $i$ filtratsiia [Stochastic differential systems. Analysis and filtering]. Moscow: Nauka [in Russian].

23 Tleubergenov, M.I. (1992). K obratnoi zadache Niutonovoi mekhaniki v veroiatnostnoi postanovke [On the inverse problem of Newtonian mechanics in probabilistic formulation]. Deponirovano $v$ VINITI ot 14.02.92 - Deposited at VINITI on February 14, 1992. (No. 499, Issue 92, 54). Moscow [in Russian].

24 Tleubergenov, M.I. (1996a). Metod dopolnitelnykh peremennykh v stokhasticheskoi zadache Helmholtsa [The method of additional variables in the stochastic Helmholtz problem]. Izvestiia Ministerstva nauki Akademii nauk Respubliki Kazakhstan. Seriia fiziko-matematicheskaia - News of the Ministry of Science Academy of Sciences of the Republic of Kazakhstan. Series of physics and mathematics, 1, 49-54 [in Russian].

25 Tleubergenov, M.I. (1996b). K voprosu razreshimosti stokhasticheskoi zadachi Helmholtsa [To the question of solvability of the stochastic Helmholtz problem]. Izvestiia Ministerstva nauki-Akademii nauk Respubliki Kazakhstan. Seriia fiziko-matematicheskaia - News of the Ministry of Science-Academy of Sciences of the Republic of Kazakhstan. Series of physics and mathematics, 3, 53-63 [in Russian].

26 Sagirov, P. (1974a). Stokhasticheskie metody v dinamike sputnikov [Stochastic methods in the dynamics of satellites]. Mekhanika. Periodicheskii sbornik perevodov inostrannykh statei - Mechanics. Periodic collection of translations of foreign articles, 5(147), 28-47 [in Russian].

27 Sagirov, P. (1974b). Stokhasticheskie metody v dinamike sputnikov [Stochastic methods in the dynamics of satellites]. Mekhanika. Periodicheskii sbornik perevodov inostrannykh statei - Mechanics. Periodic collection of translations of foreign articles, 6(148), 3-38 [in Russian].

28 Sinitsyn, I.N. (1976). On the fluctuations of a gyroscope in a cardan suspension. Izvestiia Akademii nauk SSSR. Mekhanika tverdoho tela - News of the Academy of Sciences of the USSR. Mechanics of a solid body, 3, 23-31 [in Russian]. 